(continued from page 645 )

between $\$ 7,000$ and $\$ 10,000$ ).

- Grace period: to encourage rapid publication of scientific results, the bills would offer a one-year grace period after publication during which an inventor can file a patent application. Japan currently has a six-month grace period; Europe has none. The bills would also institute a low-cost 'place-holder' process that would allow inventors to file a bare-bones application for initial review.

- Publication after 18 months: US law allows a patent to be kept secret until it is issued. In the case of a patent on the integrated circuit, the inventor used various legal devices to keep it out of the hands of the computer industry for 16 years. Japan and Europe want the US Patent Office to make a patent application publicly available after 18 months (as the Japanese system requires) to avoid such situations. - Breadth of claims: Japan, in particular, has traditionally allowed inventors to claim only a very narrow patent - one variation of a chemical structure, for example. This has forced foreign companies to cross-license technologies to Japanese companies. Recently, however, newly industrialized countries such as Korea and Taiwan have begun taking advantage of the narrow claims to move in on Japanese inventions. Japan now looks more favourably on permitting broader claims - known as a 'doctrine of equivalents' - as part of a harmonization treaty.

Although the proposed legislation reflects much of the current thinking at the US Patent Office and among US industry, its real purpose is to build a consensus for the international negotiations. Delegates at the WIPO talks have also discussed a 'nativetongue' provision that would incorporate both the original and the translated versions of an invention (to avoid a situation that often comes up in Japan, in which a faulty translation can invalidate an entire patent). And US companies are seeking a change in the Japanese law that would make it harder for companies to tie up competing patent application for years by filing multiple 'oppositions' during the evaluation period. Japanese companies are understandably resisting this effort.

WIPO negotiators are hoping to achieve a treaty by the summer of 1993 , but the talks are slowed by the one-nation, one-vote rule. That is less of a concern within GATT, in which trade determines the number of votes allotted to each country and where the agenda is set by the industrial world.

Experience has shown that such talks invariably take longer than expected. But thanks to a consensus on the need for greater harmony, the remaining question is not whether, but rather how much, the United States, Europe and Japan are willing to bend to fit the mould.

\title{
Out of many, one
}

\section{London}

THE Conservative party, fresh from its narrow electoral victory, has turned away from its philosophy of decentralization in a restructuring of science and technology policy in Britain.

Under a new arrangement announced last week, responsibility for science and technology has been transferred from the Department of Education and Science (DES) to the Cabinet Office and the new Office of Science and Technology (OST). The office will be run by the government's chief science advisor, William Stewart, and will incorporate both the Advisory Council on Science and Technology (ACOST) and the Advisory Board to the Research Councils (ABRC). ACOST advises the government on priorities in home and international science, while the ABRC communicates the needs of the research councils to the government and allocates the resulting slice of the budget.

The new body falls under the control of the Chancellor of the Duchy of Lancaster, William Waldegrave, who was previously Secretary of State for Health. This means that for the first time since 1959 there is a minister of Cabinet rank with responsibility for science.

In a statement released last week, Waldegrave indicated that the changes were motivated by the wish to have a high-ranking minister representing British science in Brussels, and reflect the government's continuing interest in science. Although the changes take effect immediately, an agenda will not be set until a reconvened Parliament approves the reorganization.

Waldegrave is also responsible for the civil service and the Citizen's Charter, an on-going programme for setting standards of public service. As such, securing the annual allocation of funds for the research councils will be his only financial mission.

Waldegrave will be assisted in his duties by Robert Jackson, who has moved from the Department of Employment. Jackson had been responsible for higher education and science when it was part of the DES from 1987 to 1990 . Although he made some enemies in the scientific community (the pressure group British Scientists Abroad has called him the 'rottweiler of academia' because of his insistence that the 'brain drain' was a myth), most commentators are pleased that the position has gone to an experienced administrator.

The creation of the Office of Science and Technology has been greeted with guarded enthusiasm from the scientific community. The chief criticism has been that the new structure further widens the gulf between the universities and polytechnics and research.
"Having someone in the Cabinet whose only financial responsibility is science is a great step ahead," commented Sir Eric Ash, rector of Imperial College, London. "But one part I do find troublesome is that the Department of Education will retain responsibility for some of the science budget. This is a problem that needs to be sorted out."

Many commentators share the view that keeping open the lines of communication between science and education will be of paramount importance. But they point out that the gap has been widening and that the previous secretary of state for education, Kenneth Clarke, gave short shrift to science.

"With the problems afflicting science at the present time, I am almost glad to see science removed from the DES, although there are dangers in that", commented Lord Flowers, chairman of the select committee on science and technology in the House of Lords. Reports from this committee have criticized the government's handling of science funding.

Lord Flowers also said that the relationships between the research councils and other government departments between the Agricultural and Food Research Council and the Ministry of Agriculture, or the Medical Research Council and the Department of Health for instance - might also benefit from increased attention. "I believe it needs a lot of thought", he says about those ties. "At the moment, the Prime Minister can decide to do anything he wants. He could prevent a lot of internecine arguments."

Given that science was barely an issue in the recent election, the creation of the OST has come as a surprise to many people in the United Kingdom. Not the least of these is the Labour Party, whose preelection manifesto proposed something remarkably similar to the OST.

"Imitation is the sincerest form of flattery," commented Jeremy Bray, Labour's science and technology spokesman, in welcoming the move. However, he maintained that the government had adopted the structure without also taking on the party's underlying strategy for science.

"Nothing has been said about the coordination of research and development across departments" says Bray. "Nothing has been said about integrating policy research and statistical services for government into the Office."

Whether the OST is the whole story or is just the first of a number of adjustments to the way that the government handles science and technology will not be clear for at least the next few months. Word from the inside has it that the shakingdown process has some way to go before the results are clear.

lan Mundell 